Kirklin, J.W., Wallace, R.B., McGoon, D.C. \& Dushane, J.W. (1965) Early and late results after intrecardiac repair of tetralogy of Fallot. Ann. Surg. 162, 578.

Lillehei, C.W., Levy, M.J., Adams, P. \& Anderson, R.C. (1964) Corrective surgery for tetralogy of Fallot. $J$. thorac. cardiovasc. Surg. 48, 556.

Mustard, W.T., Keith, J.D., Trusler, G.A., Fowler, R. \& KIDD, L. (1964) Surgical management of transposition of the great vessels. J. thorac. cardiovasc. Surg. 48, 953.

Ochsner, J.L., Cooley, D.A., McNamara, D.G. \& Kilne, A. (1962) Surgical treatment of cardiovascular anomalies in 300 infants younger than one year of age. $J$. thorac. Surg. 43, 182.
Ross, D.N. (1964) Homotransplantation of the aortic valve in the subcoronary position. J. thorac. cardiovasc. Surg. 47, 713.

Ross, D.N. (1966) International Medical Tribune of Great Britain, 30th June.

STARR, A. (1966) International Medical Tribune of Great Britain, 30th June.

TAYlor, D.G., Thornton, J.A., Grainger, R.G. \& Verel, D. (1963) Closed pulmonary valvotomy for the relief of Fallot's tetralogy in infancy. $J$. thorac. cardiovasc. Surg. 46, 77.

WATSON, H. \& RASHKIND, W.J. (1967) Creation of atrial septal defects by balloon catheter in babies with transposition of the great arteries. Lancet, i, 403.

\title{
Respiratory failure and acid-base status in hypothermia
}

\author{
M. W. MCNICOL \\ M.B., M.R.C.P.
}

\author{
Central Middlesex Hospital, London, N.W.10
}

RESPIRATORY failure is best defined in terms of deviation of arterial blood gas tensions outwith a 'normal' range (Campbell, 1965), commonly by a carbon dioxide tension greater than $50 \mathrm{mmHg}$ and an oxygen tension less than $60 \mathrm{mmHg}$. In hypothermia the first problem is in defining the "normal' values. This difficulty stems from the fact that normal man does not become hypothermic; the response of patients made hypothermic under anaesthesia reflects anaesthetic techniques almost entirely, and the findings in patients with accidental hypothermia are usually complicated by intercurrent acute respiratory infection. The changes in hibernating or poikilothermic animals provide some indication of what the normal pattern may be (Rahn, 1967 ; Robin, 1962 ; Lyman \& Hastings, 1951), but these are not entirely applicable to man. The problems in definition are further complicated by changes in blood gas tensions and $\mathrm{pH}$ due to the physical effects of change in temperature.

It is likely that accidental hypothermia is frequently complicated by respiratory failure. McNicol \& Smith (1964) found evidence of respiratory failure in four of the eight patients they studied. The hypoxaemia of respiratory failure may be an important factor in the high mortality. Acid-base disturbance is also common, the acidosis of carbon dioxide retention being found in some patients and in others metabolic acidosis associated with fall in plasma bicarbonate probably due to tissue hypoxia from a combination of arterial hypoxaemia and impaired peripheral circulation (Jones et al., 1966). I wish to discuss first the problems of diagnosis of respiratory failure and acid-base disturbance in the hypothermic patient and then to consider the ways in which these disturbances may be produced by hypothermia.

Diagnosis of respiratory failure and assessment of acid-base status in the hypothermic patient

With fall in temperature the solubility of gases increases; a liquid at a lower temperature con? tains the same quantity of gas at a lower pressure. In blood, with fall in temperature the effects produced by change in the dissociation constant of buffers and displacement to the left of the haemoglobin dissociation curve are added to increased gas solubility. In an anaerobically cooled sample of blood the carbon dioxide content of which is constant, carbon dioxide tension falls, plasma bicarbonate rises slightly and there is a marked rise in $\mathrm{pH}$. Oxygen tension falls, but oxygen saturation shows no change. The changes in carbon dioxide tension and $\mathrm{pH}$ produced in this fashion probably provide the best model for the 'normal' changes in hypothermia (Brewin et al., 1955), but the changes for oxygen do not (see below).

If the normal levels of carbon dioxide tension and $\mathrm{pH}$ in the hypothermic patient are defined by an anaerobically cooled blood sample, assessment of carbon dioxide tension and $\mathrm{pH}$ are greatly simplified, for a blood sample from the patient measured in an electrode working at its normal temperature $\left(37\right.$ or $\left.38^{\circ} \mathrm{C}\right)$ is anaerobically warmed and normality is then defined by normal ranges at electrode working temperature. This seems to remain the most useful method of assessment of acid-base and carbon dioxide tension (Patterson 
\& Sondheimer, 1966). If it is felt to be essential to express values at body temperature conversion factors can be used: for $\mathrm{pH}+0.0147 \mathrm{pH}$ unit/ degree C temperature fall (Rosenthal, 1948) and for carbon dioxide tension the nomogram of Severinghaus (1958) which is usually supplied with carbon dioxide electrode assemblies. It is doubtful if any advantage is obtained by these conversions unless the exact value of arterial carbon dioxide tension is required for the assessment of arterial oxygen tension (see below). Treatment of ventilation or acid-base disturbance should be undertaken on the measured values at the electrode temperature.

Assessment of arterial oxygen tension presents a different problem, for oxygen tension in hypothermia should be normal or increased. The arterial oxygen tension is determined by alveolar ventilation and the efficiency of alveolar-arterial oxygen transfer. Carbon dioxide tension is low indicating relative alveolar over-ventilation, although absolute ventilatory volumes are reduced. Alveolar oxygen tension is therefore high, and as hypothermia does not interfere with alveolar-arterial oxygen transfer (Hedley-Whyte et al., 1965) arterial oxygen tension should be increased above normal. Values measured at electrode temperature are higher than those at body temperature and should be corrected to body temperature using a nomogram similar to that for carbon dioxide (Severinghaus, 1958). The 'normal' values when so corrected should not be less than the normal values at normal temperature.

Clinical assessment of arterial oxygenation by examination for cyanosis is particularly misleading because of the shift in the dissociation curve of haemoglobin which changes the normal relationship between oxygen tension and oxygen saturation. Cyanosis does not appear until arterial oxygen tension is very greatly reduced. Measured values of oxygen saturation are also misleading unless approximately converted to oxygen tension at body temperature, taking into account the effects of both temperature and $\mathrm{pH}$; the Severinghaus nomogram can be used.

\section{Summary}

(1) To assess the acid-base status and adequacy of ventilation of the hypothermic patient measure arterial blood $\mathrm{pH}$, carbon dioxide tension and bicarbonate, etc., at electrode temperature $\left(37-38^{\circ} \mathrm{C}\right)$, express the results at electrode temperature and use normal values at normal body temperature for comparison.

(2) To assess adequacy of arterial oxygenation measure arterial oxygen tension at electrode temperature and convert to patient's body tempera- ture by Severinghaus nomogram. Values should be not less than normal range at normal temperature.

\section{Effect of hypothermia on lung function}

Hypothermia may affect lung function in the following ways:

(1) By alteration of the metabolic leads of the body-reduction in oxygen consumption and carbon dioxide excretion.

(2) By alteration in the mechanisms of control of respiration.

(3) By alterations in gas solubility and gas transport.

(4) By change in mechanical or other properties of the lung either primarily due to the effects of fall in temperature or secondarily due to other changes, e.g. superimposed infection, etc.

\section{Alteration of metabolic leads of the body \\ Under basal conditions oxygen consumption is} approximately halved by an $8^{\circ} \mathrm{C}$ temperature drop. Carbon dioxide production is similarly depressed. Minute volume and alveolar ventilation are reduced. Data from this laboratory (Kirby \& McNicol, unpublished work) in five patients with accidental hypothermia, several of whom had respiratory infection, showed an average minute volume of 5.5 litres and alveolar ventilation of $21 / \mathrm{min}$. Reduction in ventilation is not as great as a fall in oxygen uptake and carbon dioxide excretion; alveolar oxygen tension is therefore increased and carbon dioxide tension low. Fall in oxygen consumption is accompanied by a smaller fall in cardiac output, so that venous oxygen saturation is maintained at normal or slightly increased levels (Michenfelder et al., 1965). When shivering occurs oxygen consumption rises without change in cardiac output so that venous oxygen saturation falls (Michenfelder et al., 1965). The response of ventilation to this extra oxygen demand is not known, but the occurrence of fall in arterial oxygen saturation in anaesthetized hypothermic patients who shiver (Jones \& McLaren, 1965) suggests that the ventilatory response is also inadequate and that the hypothermic patient compensates poorly for any extra oxygen demand.

\section{Respiratory control}

Experimental hypothermia is usually studied in anaesthetized animals and often with controlled ventilation. Information on the effects of hypothermia on respiratory control is therefore scanty. In one study (Salzano \& Hall, 1960), the ventilatory response to a carbon dioxide load in hypothermic dogs was found to be diminished, but not 
greatly so. There is no evidence on the responses to hypoxaemia or acidosis or on any changes in reflexes from the lung. The frequent occurrence of under-ventilation in patients with accidental hypothermia suggests that respiratory control is abnormal.

\section{Gas solubility and gas transport}

The effect of fall in carbon dioxide tension and rise in $\mathrm{pH}$ may be important in that both of these changes tend to reduce cerebral blood flow and adversely affect cardiac function. This possibility has excited much interest in relation to hypothermic anaesthesia and it has been suggested that the addition of carbon dioxide to prevent rise in pH may be beneficial (Broom \& Sellick, 1965). The relevance of these speculations in the unanaesthetized patient is uncertain and this procedure seems unjustified in accidental hypothermia, whatever its merits under other conditions.

The altered relationship between oxygen saturation and oxygen tension is liable to produce a fall in tissue oxygen tension. At normal body temperature and $\mathrm{pH}$ with oxygen saturation of approximately $60 \%$ venous blood has an oxygen tension of $31 \mathrm{mmHg}$; tissue oxygen tension is a function of this level. In hypothermia with a temperature of $30^{\circ} \mathrm{C}$ and a $\mathrm{pH}$ of 7.50 the corresponding oxygen tension is $21 \mathrm{mmHg}$. The fall in tissue oxygen tension so produced becomes important if circulation is in any way impaired, if there is arterial hypoxaemia or if tissue oxygen consumption is not reduced by the effect of hypothermia. It is likely that tissue hypoxia which is readily produced is responsible for metabolic acidosis in hypothermia often seen in surgical patients (Brooks, 1962).

\section{Change in lung function}

The only change in lung function directly attributable to hypothermia is an increase in conducting airway dead-space due to bronchodilation (Severinghaus, 1959). Carbon dioxide excretion is not impaired (Severinghaus et al., 1957) nor is oxygen uptake (Hedley-Whyte et al., 1965) and mechanical properties show no significant change (Blair et al., 1964). There is thus no evidence that there is any specific 'cold injury' to the lung. The effect of change in lung function is, however, frequently the dominant feature in patients with accidental hypothermia. Reduction in ventilation and depression of cough predispose to collapse of alveolar units and larger segments of lung. Infection is frequently superimposed. Continued perfusion of under-ventilated alveoli causes severe arterial hypoxaemia. Respiratory depression is not uncommon although its cause is obscure ( $\mathrm{McNicol}$ \& Smith, 1964). Severe acidosis may occur especially if tissue perfusion is impaired (Jones et al., 1966) and this may further depress cardiac and respiratory function.

\section{Summary}

The patient with accidental hypothermia may show under-ventilation, hypoxaemia or acidosis. The methods of diagnosis have been discussed and the information on the effects of hypothermia on lung function summarized.

\section{References}

Blair, E., Esmond, W.C., Attar, S. \& Cowley, R.A. (1964) The effect of hypothermia on lung function. Ann. Surg. $160,814$.

Broom, B. \& Sellick, B.A. (1965) Controlled hypercapnia in open heart surgery under hypothermia. Lancet, ii, 452.

Brewin, E.G., Gould, R.P., Nashat, F.S. \& Neil, E. (1955) An investigation of problems of acid-base equilibrium in hypothermia Guy's Hosp. Rep. 104, 177.

Brooks, D.K. (1962) In: Modern Trends in Anaesthesia, Vol. 2. Butterworths, London.

Campbell, E.J.M. (1965) Respiratory failure. Brit. med. J. i, 1451 .

Hedley-Whyte, J. Pontopoppidau, H., Laver, M.B., Hallowell, P. \& Bendixen, H.H. (1965) Arterial oxygenation during hypothermia. Anaesthesiology, 26, 595.

Jones, H.D. \& McLaren, C.A.B. (1965) Postoperative shivering and hypoxaemia after halothane nitrous oxide and oxygen anaesthesia. Brit. J. Anaesth. 37, 35.

Jones, R.H.T., Bourdillon, R.E., FinN, R. \& Martindale, K. (1966) Hypothermia associated with pneumonia and acidosis. Postgrad. med. J. 42, 273.

Lyman, C.P. \& Hastings, A.B. (1951) Total $\mathrm{CO}_{2}$, plasma $\mathrm{pH}$ and $\mathrm{PCO}_{2}$ of hamsters and ground squirrels during hibernation. Amer. J. Physiol. 167, 633.

McNicol, M.W. \& SMith, R. (1964) Accidental hypothermia. Brit. med. J. i, 19.

Michenfelder, J.D., Uihlein, A., DAw, E.F. \& Theye, R.A. (1965) Moderate hypothermia in man: haemodynamic and metabolic effects. Brit. J. Anaesth. 37, 738.

Patterson, R.H. \& SONDheimer, H.M. (1966) Assessing acid-base metabolism with samples of arterial blood obtained from hypothermic subjects. J. surg. Res. 6, 18.

RAHN, H. (1967) Gas Transport from Environment to Cell in Development of the Lung. Churchill, London,

RoBIN, E.D. (1962) Relationship between temperature and plasma $\mathrm{pH}$ and carbon dioxide tension in the turtle. Nature (Lond.), 195, 249.

Rosenthal, T.B. (1948) The effect of temperature on the pH of blood with plasma in vitro. J. biol. Chem. 173, 25.

Salzano, J. \& Hall, F.G. (1960) Effect of hypothermia on ventilatory response to carbon dioxide inhalation and carbon dioxide infusion in dogs. J. appl. Physiol. 15, 397.

Severinghaus, J.W. (1958) In: Handbook of Respiration. Saunders, Philadelphia.

SeveringhaUS, J.W. (1959) Respiration and hypothermia. Ann. N.Y. Acad. Sci. 80, 384.

Severinghaus, J.W., Stupfel, M.A. \& Bradley, A.F. (1957) Alveolar dead space and arterial to end-tidal carbon dioxide differences during hypothermia in dog and man. J. appl. Physiol. 10, 349. 